\section{In the News}

Congratulations to Jim Neal, director of libraries at Johns Hopkins University, for being named ACRL's 1997 Academic/Research Librarian of the Year. Jim's many accomplishments are outlined on page 269. Be sure to join him at a reception in his honor at the ALA Annual Conference in San Francisco on Monday, June 30, from 4:30-6:00 p.m. Announcements of ACRL's other award winners will be published in the May issue.

Other ACRL business reported in this issue includes:

- the final approved version of the "Guidelines for Instruction Programs in Academic Libraries" (page 264);

- the actions taken by ACRL's Board of Directors at their Midwinter meetings (page 260);

- a report of the University Libraries Section's activities at ALA's Midwinter Meeting (page 242);
- responses to questions posed by ACRL's Board of Directors to the two candidates for ALA president, Ken Dowlin and Ann Symons (page 270);

- a list of ACRL members running for ALA Council (page 275);

- and a list of ACRL preconferences that will be offered prior to the ALA Annual Conference in San Francisco (page 262).

Also in this issue, Fred Jenkins and Nancy Courtney continue our Internet Resources series with a look at the best sites for classics (page 255). John Stemmer and John Tombarge discuss a program at the Virginia Polytechnic Institute that brings the librarians to the faculty departments (page 244). And Stacy Kimmel and Scott DiMarco outline the ideal interview schedule from the candidate's viewpoint (page 249). - Mary Ellen K. IJavis Editor \& Publisher medavis@ala.org

\title{
Journal of Phase Equillhria
}

\section{SUBSCRIBE FOR ONE YEAR AND SAVE 20\% \%}

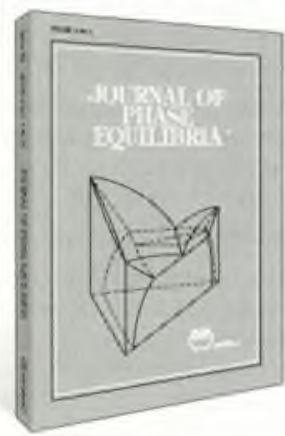

This journal includes original research on attaining or preventing phase equilibria, and the use of data when evaluating alloys for high-tech applications.

Includes reliable research, applications, updates and critical phase diagram evaluations authored by international experts.

"First-time subscribers only. Call 1-800-336-5152 for a FREE preview package, or mail this coupon.

Mail to: Member Services Center ASM International, Materials Park, $\mathrm{OH}$ 44073-0002
Please send a FREE preview package for the Journal of Phase Equilithria to:

Name

Title Company Name

Address

City

State ZIP Country

Phone

Fax

E-mail 